ISSN: 2036-5438

\title{
A Federal Turn? The European Union's Response to Constitutional Crises in the Member States
}

by

Matteo Bonelli* 


\section{Abstract}

The EU has not yet found effective answers to constitutional crises in its Member States, in particular Hungary and Poland. Due to systemic problems of compliance with the common values of Art. 2, the legitimacy of the EU constitutional order and its smooth functioning are under threat, but the EU lacks instruments of direct enforcement and coercion. Several authors have therefore proposed to 'federalize' EU mechanisms and to guarantee to EU institutions, in particular the Court of Justice, more powers to intervene vis-à-vis Member States. However, the current Treaty framework presents a series of obstacles to federal-like enforcement. Solutions to national crises must ultimately respect the constitutional balance between the Union and the Member States.

\section{Key-words}

European Union, federalism, international organisation, rule of law, Hungary, Poland 


\section{Introduction}

Between the spring and summer of 2017, the adoption of controversial pieces of legislation in Hungary and Poland once again stirred the debate on how the EU could

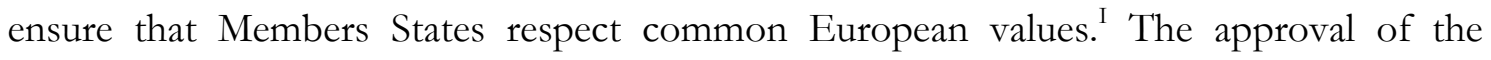
'Higher Education Law' and of restrictive measures against NGOs in Hungary, and the radical reforms of the judiciary proposed by Law and Justice in Poland, ${ }^{\text {II }}$ have met with harsh criticism from key European actors. Consequently, there has been a renewed call for stronger action by EU institutions. All EU institutions intervened in the debate: the European Parliament; ${ }^{\mathrm{III}}$ the Commission, which has launched infringement procedures against Hungary $^{\text {IV }}$ and Poland, ${ }^{\mathrm{V}}$ and has adopted, under the Rule of Law Framework, a new (the third) Rule of Law Recommendation directed at the Polish government; ${ }^{\text {VI }}$ and even the Council has for the first time formally discussed the situation of the rule of law in Poland, ${ }^{\text {VII }}$ after a long period of inaction (Oliver and Stefanelli 2016).

While these recent developments may signal that EU institutions are increasingly willing to tackle on-going constitutional crises in the Member States, until today the EU's reaction has been widely considered insufficient and ineffective. ${ }^{\text {VIII }}$ Thus, many proposals have been formulated with the aim of strengthening the EU's capacity to respond to constitutional crises in the Member States. ${ }^{\text {IX }}$ Several of these proposals seem to have been inspired, explicitly or implicitly, by mechanisms available in federal systems to enforce federal 'values' and the federal constitution vis-à-vis their sub-national entities. In particular, there has been an emphasis on strengthening of judicial procedures, and much of the discussion has been conducted in terms of enforcement of values Jakab and Kochenov, 2017).

The aim of this paper is to understand whether 'federal solutions' - that is, replicating mechanisms and procedures available in federal systems - may help the EU in addressing constitutional crises in its Member States. The paper posits the question with reference to two possible models for the EU's intervention: federal systems, and regional and international organisations (IOs) engaged in democracy and human rights' protection. Both types of entities aim to uphold the basic values of their polities, but follow contrasting models. First of all, the nature and relevance of the challenge these entities face depends on 
whether problems arise in a federal state or in an IO. Secondly, the mechanisms and procedures of these entities diverge in many ways. This work contrasts the EU's structure with the two systems and then reflects on whether the Union could and should aim to replicate the solutions developed in federal systems. It will be argued, however, that there are several obstacles to the transformation of EU values' oversight (Closa and Kochenov, 2016) into federal-like enforcement. ${ }^{\mathrm{x}}$ Thus, the conclusion of this work discusses other possible avenues for the shaping of a system that can better safeguard the founding values of the Union.

\section{Upholding values in multilevel systems: the nature of the question}

It is a traditional exercise in European studies to present (con)federal states and IOs as two alternatives models to conceive and understand the EU (Von Bogdandy 2012). However, both types of systems have a common element, in that they often affirm in their founding documents - constitutions, statutes, charters, and so on - a set of politicalconstitutional values, which are deemed to be shared by all the actors of the systems. Democracy, the rule of law, and human rights feature most prominently among these common values.

For federal states, this is a traditional and perhaps essential feature of their constitutions (Gavison 2002). ${ }^{\mathrm{XI}}$ However, in international and regional organisations, references to democracy and other shared political values are a more recent phenomenon. Only some organisations, such as the Council of Europe (CoE) or the United Nations (UN), have been committed to the protection of human rights and to other political objectives since their inception. For several other IOs with a more limited mandate, as well as for regional organisations originally born as regional trade agreements - the EU itself is an example (de Burca 2012) - this development came about only years or even decades after their inception. Several factors may have led to this: the new geopolitical context triggered by the end of the Cold War; the spreading of democracy and the rule of law as 'global goods' (Franck 1992, Carothers 1998); a normative concern for the protection and promotion of democracy and human rights; and the desire of regional organisations to broaden their originally limited mandate (Closa 2017, Duxbury 2011). 
In most cases, federal constitutions, and statues or other protocols of IOs, first introduce a general clause, where they refer to the concrete values shared by all members of the entity. Then they establish procedures through which the central organs can intervene in order to guarantee these values. Whilst the objective is similar - upholding the common values of the system - both the way in which the general clauses are framed, and the procedures that are put in place, are crucially different. This section looks at the general clauses and aims to understand why both types of systems require their Member States' to respect those political values, while section 3 focuses on procedures and mechanisms of enforcement or oversight.

Exploring IOs' clauses first, the best example is Art. 3 of the CoE Statute, which affirms that 'Every member of the Council of Europe must accept the principles of the rule of law and of the enjoyment by all persons within its jurisdiction of human rights and fundamental freedoms'. Other regional organisations, in Latin America, ${ }^{\mathrm{XII}}$ the Caribbean, ${ }^{\mathrm{XIII}}$ and Africa, ${ }^{\text {XIV }}$ contain similarly phrased clauses (Closa et al. 2016, Closa 2017). On the other hand, Art. 4 of the UN Charter contains a more generic formulation: 'Membership in the United Nations is open to all other peace-loving states which accept the obligations contained in the present Charter'. It is in any event argued that these obligations include the human rights norms of the Charter and those created by the other universal UN human rights documents. In several IOs, these clauses are to be found outside the original constitutive documents, in Charters or Declarations attached to them. ${ }^{\mathrm{xV}}$ The fact that they are located in successive documents shows the evolution of the mandate of the relevant organisation and also indicates that the inclusion of these clauses is a relatively recent phenomenon. The provisions are often framed in terms of requirements for acquiring membership of the organisation, ${ }^{\mathrm{XVI}}$ or as unspecified commitments undertaken by the organisation and its Member States. ${ }^{\text {XVII }}$ They almost never define in detail the values to which they refer, nor do they provide clear standards to be respected by the Member States of the organisation.

Within federal systems, one of the basic functions of national constitutions is to declare the basic values of the polity as well as to offer protection for human rights, as seen above. This is true for unitary, ${ }^{\mathrm{XVIII}}$ regional, ${ }^{\mathrm{XIX}}$ and also of course federal states. The following analysis covers specifically the latter type of entities. In an analogous way to other state systems, federal constitutions in most cases begin with an enunciation of the basic rights 
and values of the polity, as in Art. 1 of the German Constitution on human dignity, Section 1 of the Spanish Constitution, ${ }^{\mathrm{xx}}$ and the well-known preamble of the US Constitution. In addition, federal constitutions often contain other provisions positing more precise requirements for the organisation of power in their sub-entities. Good examples of this are Germany and the United States. The German Basic Law states in Art. 28: 'The constitutional order in the Länder must conform to the principles of a republican, democratic and social state governed by the rule of law, within the meaning of this Basic Law'. XXI The US Constitution provides in in Art. IV Section 4: 'The United States shall guarantee to every State in this Union a Republican Form of Government'. ${ }^{\text {XII }}$ Other constitutions are less explicit but contain similar provisions which expect sub-entities to respect democratic requirements. ${ }^{\text {XIII }}$

When it comes to the EU, the Treaty of European Union (TEU) proclaims in Art. 2 the founding values of the organisation. These values, Art. 2 continues, 'are common to the Member States'. Moreover, according to Art. 49 of the TEU, respect for the values of Art. 2 is a condition for acquiring membership of the EU: 'Any European State which respects the values referred to in Article 2 and is committed to promoting them may apply to become a member of the Union'. Moreover, Art. 49 affirms that 'the conditions of eligibility agreed upon by the European Council shall be taken into account'. This is a reference to the Copenhagen criteria, including the political criterion of 'stability of institutions guaranteeing democracy, the rule of law, human rights and respect for and protection of minorities'. XxIv

At a general level, the provisions of federal systems, IOs, and the EU share some basic features. First of all, they contain a similar message: the members of those entities must be committed to the set of common values affirmed in the basic document of the system. Secondly, the values proclaimed in the documents mentioned above are conceptually similar - democracy, the rule of law, and human rights - and they are rarely defined in detail in the founding documents of the organisations. The exception is the concept of human rights: federal constitutions often provide a legally binding bill of rights, and IOs too may contain binding human rights charters or conventions - as in the EU, the CoE, and the Organization of American States (OAS) - or list more specific rights in other documents. ${ }^{\mathrm{xxv}}$ Finally, as shall be seen later, procedures are put in place in order to 
guarantee respect for these general clauses. On closer examination however, the systems may be said to have some significant differences.

In the first place, whereas IOs present their values as requirements for membership, federal states do not make this connection explicit. Even where they still regulate possible accession of new members, such as in Article 4 Section III of the US Constitution, ${ }^{\mathrm{XxVI}}$ they do not pose specific conditions for membership. The fact that accession of new entities has been, in most cases, out of the question for decades (at least in ordinary circumstances), has prevented further development of clear policies on the topic.

More significantly, the provisions of the two systems are different in nature, as indicated by the different theoretical frameworks the doctrine has attached to them. In international and regional organisations, the concept most often used is that of 'democracyprotecting clauses' (Closa 2016). In federal states, the reference is to the concept of 'constitutional homogeneity' and the provisions are thus defined as 'homogeneity clauses', a term derived in particular from the German literature (Schmitt 2008). ${ }^{\text {XXVII }}$ What the two concepts evoke is that that the role of the provisions is not identical, despite the similarities in terms of general message and content. More specifically, the two expressions denote different perspectives: IOs adopt an 'external' perspective, while federal systems have a more 'internal' one. In sum, this suggests a different extent of engagement with, and intrusion into, the activities of the sub-entities.

The term 'democracy-protecting clauses' essentially suggests that these provisions are in place to offer an external guarantee to national democratic systems when the latter experience some difficulties. Thus, they offer to international organisation the possibility to intervene - via the procedures analyzed in Section 3 - in cases of crisis, such as military and civil coups d'etat, or similar events. Whilst the effects of such a crisis are felt mainly within that particular Member State, the regional or international organisation may claim to have an interest to intervene in order to uphold democracy as a shared value of the system. However, a national crisis does not directly affect the functioning of the organisation itself, nor other Member States and their citizens. At most, taking measures is a matter of credibility for the organisation and the Member States, which may want to distance themselves from an 'illiberal' state, run by authoritarian figures.

In federal states however, a democratic crisis at the sub-national level affects the entire system more profoundly. The very functioning of the federal system depends on the 
preservation of the degree of cohesion implied by the concept of 'constitutional homogeneity'. Due to the higher level of interdependence, all the actors of the system feel the effects of a sub-national problem: the central government, other sub-entities, as well as all citizens of the state. ${ }^{\text {XxvII }}$ The functioning of the whole body of federal law is undermined in these circumstances, and so is the legitimacy of the exercise of power by any authority within the system. This is thus an internal perspective: federal institutions are called to address the crisis primarily to defend their own authority and legitimacy.

The two types of frameworks have been applied to the EU, as the Union shares some characteristics of both systems. ${ }^{\text {XxIx }}$ For example, the TEU establishes that the values of Art. 2 are a requirement for membership, through the reference contained in Art. 49. This is a trait similar to IOs. Similarly, as will be discussed in Section 3, the Art. 7 system envisages a limited intervention of EU institutions in Member States' domestic affairs. The remarkable diversity of the Member States' constitutional systems must also be taken into account. ${ }^{\mathrm{xx}}$ Some writers that argue that the concept of constitutional homogeneity cannot be applied to the EU make reference precisely to the heterogeneity of current constitutional models (Von Bogdandy 2009, Schroeder 2016). According to this line of thought, there would be no bomogeneity in terms of constitutional values in the EU. Moreover, while in federations there is a clear principle of hierarchy of federal norms over state ones, ${ }^{\mathrm{XXx}}$ which applies also to constitutional norms proclaiming the values, under EU law, the principle of primacy is confined to areas 'within the scope of EU law'. The values of Art. 2 are however considered to be, mainly outside the scope of EU law stricto sensu, as the EU does not possess a general competence to legislate on democracy, the rule of law, or human rights, but only more specific, limited legal bases. ${ }^{\text {XXXII }}$ Therefore, there is no clear hierarchy in this respect.

Looking at the effects of a Member State's breach of values, the EU again shows similarities with both systems. Yet the effects of a national problem are more severe here than in any other IO. In the first place, there are the obvious symbolic consequences. The credibility of the EU as a project committed to the ideal of constitutionalism - reflected in the expression 'a Union of values' - is undermined if a Member State fails to respect the values of Art. 2 of the TEU. Prima facie, this is similar to other IOs, which are also committed to protecting and promoting the same values, as the $\mathrm{CoE}$ or regional organisations in South America and Africa. However, the consequences of non-adherence 
are more severe and typical to the EU. The Union has in fact put in place a strict policy of human rights and democratic conditionality in its external relations, in particular in its development, neighborhood and enlargement policies (Cremona 2011, Larik 2016). A question that arises then is: how credible and effective can external policies be if the EU demands of third countries what its own Member States fail to guarantee?

However, the consequences of national violations of Union values go beyond the symbolic level. Some authors have argued that the 'all-affected principle' is applicable to the EU system too (Closa 2016; Muller 2016). The idea is that the 'externalities' of a Member State's constitutional crisis are felt throughout the entire Union, at various levels: EU institutions, other Member States, and EU citizens. As provided by Art. 10 of the TEU, the democratic legitimacy of the entire EU system rests on a double channel: citizens are represented directly through the European Parliament, but also by the governments in the European Council and in the Council. Thus, the functioning of the EU democratic system depends on the functioning of all national democratic systems. Democratic failures of just one Member State affect the entire framework because they interrupt the democratic channels of representation and thus affect the legitimacy of the organisation. ${ }^{\text {XXXIII }}$ Consequently, EU institutions, other Member States, and all citizens of the Union, both in their capacity as national citizens and as EU citizens, are affected by democratic and rule of law problems even in a single Member State. From this point of view, the effects are more akin to a federal system, as described above. The EU constitutional order shows in this respect a level of interdependence similar to federal systems.

Finally, there is another set of consequences which is unique to the EU system. The functioning of key elements of the EU legal order depends on Member States' respect for the values of Art. 2 of the TEU. Many fields of EU law, from the internal market to the Area of Freedom, Security and Justice, are based on the principle of mutual recognition, which demands to national authorities to recognise each other's administrative and judicial decisions. The system of mutual recognition, in turn, is predicated on the existence of mutual trust between Member States. What implies and justifies mutual trust, as held by the Court of Justice of the European Union (CJEU), is the 'fundamental premiss that each Member State shares with all the other Member States, and recognises that they share with it, a set of common values on which the EU is founded, as stated in Article 2 TEU' ${ }^{\text {xxxIv }}$ In 
EU instruments based on mutual recognition, this premise is translated into a presumption that all Member States respect the values of Art. 2 and thus they can trust each other. However, if and when systemic problems of compliance with Art. 2 arise in a Member State, the whole system is put under pressure. This has been shown in cases such as N.S. ${ }^{\mathrm{Xxxv}}$ and more recently Aranyosi, ${ }^{\mathrm{xxxI}}$ where the CJEU, under the influence of European Court of Human Rights (ECtHR) jurisprudence, ${ }^{\text {XxxvII }}$ was forced to recognise that the mutual trust presumption is rebuttable in certain, limited circumstances. In the medium term, however, if systemic problems remain widespread throughout the Union, and if the $\mathrm{EU}$ is unable to adequately address them, the very existence of the general presumption may be called into question, thus undermining the whole mutual trust-mutual recognition structure. In simple words: systemic problems of compliance with the values of Art. 2 - democracy, the rule of law, human rights - may disrupt the smooth functioning of EU legislation. This is possibly the most distinguishing feature of the EU as compared to traditional IOs within the ambit of this paper.

To summarise the findings of this section, both IOs and federal systems proclaim in their basic documents their aim to uphold a set of political-constitutional values: most often, they refer to democracy, the rule of law, and human rights. In regional and international organisations this is a recent and growing phenomenon. Provisions of constitutions, statutes, and charters specify conditions for sub-entities. In the case of IOs, this is generally done by establishing membership requirements, while federal states are more explicit in setting conditions for the exercise of authority at the local level. These provisions are however often understood differently. In IOs, they are categorised as 'democracy protecting clauses', while in federal systems as clauses of 'constitutional homogeneity'. The concepts envisage two distinct types of intervention and a different extent of central intervention into local systems. Both types of framework have been applied to the EU, which seems to share some characteristics of both models. However, it is not entirely comparable to either of the systems. Compared to IOs, the consequences of Member States' constitutional crises are more severe and affect the entire system of the EU. Whilst there are some elements common to federal systems, the EU seems to lack the homogeneity typical of federations and more generally the 'subordination which places the centre above the periphery and empowers it to make demands of the latter' (Hanschel 2017: 265). So, while there is a 'federal dimension' to the crises the EU is facing in Hungary 
and Poland, the questions raised pose some specific and distinctive dilemmas for EU institutions.

\section{Upholding values in multi-level systems: mechanisms}

In addition to the general clauses outlined in the previous section, IOs and federal states also put in place concrete procedures and mechanisms to safeguard democracy, the rule of law, and human rights. This part of the work describes the main models adopted by the two types of bodies and compares the EU procedures to both systems.

Regardless of the diverse institutional arrangements, the procedures of IOs share a number of fundamental features. ${ }^{\text {XxxvIII }}$ First, the procedures created are political ones. The political bodies of the organisations representing Member States' national governments take crucial decisions, which in most cases require (at least) a qualified majority. ${ }^{\text {Xxxix }}$ Judicial bodies, even where these exist, are not involved in the deliberations on democracy protection. Human rights courts, such as the ECtHR in the $\mathrm{CoE}$ or the Inter-American Court of Human Rights can only decide on specific cases of breach of individual rights, but are not called on to deliberate on the overall democratic and rule of law situation in a Member State. Secondly, the procedures can be activated only in cases of qualified violations, such as 'serious' violations ${ }^{\mathrm{XL}}$ of the common values, or in even more circumscribed cases. For example, the African Union allows the suspension of a Member State only when a government takes power 'through unconstitutional means'. ${ }^{\text {XLI }}$ In their concrete practice, the African Union, the OAS and the Commonwealth have intervened mostly in cases of military coups.

The third, and most relevant, common element of democracy-protecting systems is the type of intervention they envisage. The procedures are based on an approach that envisages sanctions, suspension, and/or expulsion of the Member State responsible for the breach of the common values. The aim is to isolate the Member State from the organisation and from the other states. In the $\mathrm{CoE}$, for example, according to Art. 8 of the Statute, the Committee of Ministers can suspend the rights of representation of the Member State, demand its withdrawal, and if the latter request is not complied with, provide for its expulsion. Similarly, the UN Charter provides for the possible suspension and expulsion of a Member State, ${ }^{\text {XLII }}$ while the OAS ${ }^{\text {XLIII }}$ and the African Union ${ }^{\text {XLIV }}$ can only call for 
suspension. The paradigm is thus clear: the organisation and the other Member States distance themselves from the 'undemocratic' one, hoping that political and diplomatic isolation from regional partners would force the government in question to desist from undermining the common values of the organisation. There is no form of direct intervention or enforcement on the ground, but merely the hope that international intervention would mobilize internal opposition. Finally, it must be said that all the institutional designs mentioned above leave a wide margin for states to exercise their discretion on whether or not to tackle a specific breach and eventually apply sanctions. The discretion is evident also in the fact that often the procedures do not provide detailed steps to be followed, but are phrased rather generically. The concrete practice is therefore all but coherent, with frequent accusation of double standards when sanctions are used (Duxbury 2011: 280).

The range of instruments available to federal systems is radically different. First, federal constitutions put in place a combination of political and legal mechanisms. Judicial actors, in particular federal constitutional courts (or federal supreme courts), therefore play a key role in ensuring that local actors comply with basic values affirmed in the constitution. Secondly, intervention is allowed even in ordinary cases. This is to say that a violation does not need to be qualified as 'serious'. Finally, a wide range of instruments of enforcement are available, allowing for a more direct interference with the sub-entities. Rather than imposing sanctions, federal systems aim to enforce the common obligations directly and do not rely on the will of the party in question. Mechanisms of coercion are available, as the common values affirmed in the constitution are often considered binding federal law and can be enforced both in ordinary ways, as any other piece of legislation, and also with special procedures. In most cases anyway, it is unnecessary to make use of the special procedures, which are clauses to be used ultima ratio in extreme circumstances. Questions on the enforceability of federal law against local authorities are treated as ordinary questions of compliance, rather than special ones. This, as shall be seen, is not (yet) the case for the EU.

The system in place in Germany offers an adequate illustration of these three fundamental differences. There are of course political channels, which can be used to resolve any conflict between the two levels, both informal and formalized. One of these formal channels is the possibility of 'federal oversight', according to which the Federal 
government can supervise the implementation of legislation by the Lander. ${ }^{\mathrm{XLV}}$ But the Federal Constitutional Court (FCC) plays a crucial role in ensuring respect for the common constitutional values too. The Court can verify whether a Land laws comply with the Basic Law, ${ }^{X L V I}$ including the human rights proclaimed in the constitution, the principles of Rechtsstaat and human dignity, and any other provision affirming the common values of the organisation. The jurisdiction of the FCC does not depend on whether a matter falls within the competence of the federal state or the Lander, as is the case for the CJEU. Moreover, the supremacy clause of Art. 31 of the Basic Law (BL) does not present any exception. Similarly, the bill of rights of the German constitutional court is always applicable, irrespective of which authority exercises its powers in a concrete case. ${ }^{\text {XLVII }}$ Furthermore, the FCC has at its disposal a typical instrument of 'militant democracy': banning political parties. ${ }^{\text {XLVIII }}$

There is also an emergency clause in Art. 37 of the Basic Law - the 'federal execution' or 'federal coercion' clause -, according to which, if and when a Land 'fails to comply with its obligations under [the] Basic Law', the Federal Government 'may take the necessary steps to compel the Land to comply with its duties', after obtaining the consent of the Bundesrat. This is another political mechanism, as is often the case with federal emergency clauses. Art. 37 has never been used and is intended only as a last resort emergency provision. It is nonetheless relevant as it explains extremely well how federal emergency measures differ from those of IOs. As the second section of Art. 37 clarifies, there are in the system of federal execution strong elements of coercion, allowing for direct intervention in the affairs of the Land, which in the most extreme circumstances may even permit the deployment of police and/or armed forces on the ground. ${ }^{\text {XLIX }}$ The concrete measures which can be taken, in any case, are not specified in the provision, thus leaving the Federal Government with a wide discretion to take the actions it considers most appropriate to addressing the problem.

A provision modeled on Art. $37 \mathrm{BL}$ can also be found in another European semifederal system, that of Spain. Art. 155 of the Spanish Constitution allows the Government to intervene when a community 'does not fulfill the obligations imposed upon it by the Constitution or other laws, or acts in a way seriously prejudicing the general interests of Spain'. The system envisages two phases: the first is a simple request to abide by the Constitution and other obligations, whilst the second allows for real enforcement. In the 
latter phase, coercion is possible and resistance against federal intervention may constitute criminal disobedience (López-Basaguren, 2017). The provision was activated for the first time in October 2017 against Catalonia, in the aftermath of the crisis generated by the independence referendum. ${ }^{\mathrm{L}}$ Moreover, Spain has in place a similar system of human rights' protection and the Central government has the power to challenge enactments and decisions of the Autonomous Communities before the Constitutional Court. ${ }^{\text {LI }}$ Finally, there are instruments of militant democracy, including the power to ban political parties. ${ }^{\text {LI }}$

The US Constitution provides for a combination of judicial and political mechanisms too. The 1791 Bill of Rights, which originally covered only the action of federal actors, through the doctrine of 'incorporation' (Sullivan and Feldman, 2013) has become binding on state authorities and is today judicially reviewable by the US Supreme Court. Section V of the Fourteenth Amendment allows federal congress to enforce the provisions of the amendment, including the obligations provided by the first Section. On the other hand, the guarantee clause of Art. IV Section 4 is not justiciable, and poses an 'essentially political question', as the US Supreme Court held in Luther v Borden ${ }^{\text {LIII }}$ and then confirmed in Baker v Carr. ${ }^{\text {LIV }}$ It is therefore the responsibility of political actors - President and Congress - to intervene to ensure that every State maintains 'a Republican Form of Government'. Furthermore, Art. IV Section 4 contemplates another form of federal intervention. Ultima ratio, there is the option for the President of the United States to federalize the National Guard, placing it under the direction of federal officials, in order to ensure the execution of the laws of the United States', ${ }^{\text {LV }}$ as happened in several cases relating to the enforcement of de-segregation decisions between the end of the 1950s and the beginning of the 1960s. ${ }^{\text {LVI }}$ However, the threat of military intervention, despite still being in the background, does not play a real role in current disputes on the enforcement of national law (Tushnet 2017).

In federal systems - even in those formally based on the principles of exclusivity and equality between the federal level and the federal units, such as Belgium ${ }^{\text {LVII }}$ - there is ultimately a clear hierarchy between the federal constitution, where the basic values of the polity are affirmed, and the statues and laws of the sub-entities. Moreover, and most significantly, all the federal systems analysed provide for instruments through which central authorities, both political and judicial, can take direct action in the local entities. All things considered, these instruments show the position of superiority of the central state. 
How does the EU system compare to the two models outlined above? It is widely known that the main instrument that the EU has at its disposal to protect values in Member States is provided by Art. 7 of the TEU (Sadurski 2010). Art. 7 contains two separate mechanisms. Art. 7(1) establishes a preventive procedure, according to which the Council, voting at a fourth-fifths majority and after obtaining the consent of the European Parliament, may determine the existence of 'clear risk of a serious breach' of the values of Art. 2 of the TEU. According to Art. 7(2), on the other hand, the European Council can establish at unanimity, prior consent of the EP, that a Member State has breached EU values in a 'serious and persistent' manner. Following a first determination under 7(2), the Council, acting at qualified majority, can impose sanctions on the Member State in question. Art. 7(3) offers merely one example of the type of sanctions which can be imposed, namely suspending the voting rights of the Member State in the Council. ${ }^{\text {LIII }}$

The mechanism shares several characteristics with the procedures of IOs discussed in the previous paragraphs. It is indeed a political procedure (Sadurski 2010, Kochenov and Pech 2015), controlled by EU political actors - Council and European Council, and the Parliament - and almost completely excluding the Court of Justice, which can only review

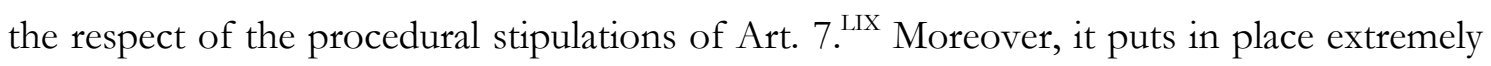
demanding voting thresholds, even higher than some other IOs: four-fifths of the votes in the Council for a simple determination of a risk of a breach, and unanimity for Art. 7(2). ${ }^{\mathrm{LX}}$ There are also similar substantive thresholds for action: a 'clear risk of a serious breach' in Art. 7(1) and a 'serious and persistent breach' in Art. 7(2).

However, the EU system does present some peculiar traits. Art. 7 does not allow for the expulsion of a Member State, something that is possible in several IOs, including the Council of Europe and the United Nations. In an even more distinctive manner, it does not allow for the full suspension of a Member State. The Council may only suspend 'certain of the rights deriving from membership'. ${ }^{\text {LXI }}$ Moreover, when it decides on sanctions, the Council 'shall take into account the possible consequences of such a suspension on the rights and obligations of natural and legal persons'. ${ }^{\text {LXII }}$ Thus, whilst it is true that the EU endorses the 'sanctions approach' of other IOs and lacks a form of direct intervention in the political and legal order of the Member State, the concrete sanctions system is specific to the EU. The clause on the rights and obligations of natural and legal persons is also unique and hints at the extreme interdependence of the EU system, indirectly referring to 
pillars of EU law such as free movement and Union's citizenship. It is not hard to imagine how a decision taken under Art. 7 might interfere with the legal position of EU citizens or businesses that are somehow linked with the Member State in question. Finally, the involvement of the Court in the procedure, although limited, is also a remarkable aspect of the EU system as compared to other IOs.

It remains that the Art. 7 system does not have the same capacity to intrude into national legal systems as the 'traditional' EU law enforcement mechanism. One of the main strengths of the EU legal order is indeed the combination of institutional enforcement via the infringement procedure of Art. 258 of the Treaty of the Functioning of the EU (TFEU), with individual enforcement in national courts - supported by the CJEU in preliminary rulings - thanks to the doctrines of primacy and direct effect of EU law. This combination of instruments has made the EU 'the most effective international legal system in existence, standing in clear contrast to the typical weakness of international law and courts' (Alter 2003: 1). These mechanisms are however available only within the scope of EU law. ${ }^{\text {LXIII }}$ Since the EU does not have a general competence to regulate the organisation of national democratic and rule of law institutions, or to adopt general human rights norms, several potential breaches of EU values cannot be tackled through a Commission infringement action or through individual cases before national courts. Outside the scope of EU law, Art. 7 is the only formal option, because it is applicable across the board, irrespective of whether or not a Member State is acting within the scope of EU law. ${ }^{\text {LXIV }}$ However, there is a range of softer political instruments, the most important of which is the Commission Rule of Law Framework. ${ }^{\text {LXV }}$

Hence, whilst within the scope of EU law the EU has at its disposal federal-like systems of legal enforcement, when a situation is not covered by substantive EU law, institutions can only protect the values of Art. 2 through the procedures of Art. 7. The latter shares several characteristics with comparable systems of international and regional organisations, despite the presence of some traits specific to the EU legal order. Outside the scope of EU law, the EU lacks any possibility of direct intervention: the European Union Charter of Fundamental Rights (EUCFR) is not applicable, there are no instruments of militant democracy available, and of course the EU does not have an army to deploy on the ground. Ultimately, it relies for coercion on the authorities of its Member States. 
The analysis conducted in these two sections explain the difficulty that the EU faces in protecting its founding values. On the one hand, the EU is obliged to intervene effectively, because constitutional crises in the Member States may affect its credibility, legitimacy, and the very functioning of its political and legal order. This necessity is matched by growing expectations that the EU is able to respond firmly and effectively. On the other hand, the mechanisms that EU institutions have at their disposal are significantly weaker than those available within the scope of EU law. The EU is thus stuck in the middle between more traditional IOs and federal states; whilst the difficulties it encounters may present some federal dimensions, the procedures are largely international in nature. This reading of the current crises has led several authors to suggest a federalization of the system in order to better protect democracy, the rule of law and human rights.

\section{A federal turn? Ideas and obstacles}

It remains to be seen whether federal procedures such as those mentioned above can provide a platform for strengthening the EU's mechanisms, what the likely obstacles to the development in a federal sense of EU values' oversight are, and the possible alternatives to a federal transformation. This fourth section of the paper reflects on a possible reconfiguration of the EU system in a federal sense, assessing its feasibility and desirability. The analysis conducted moves from the constitutional framework offered by the current Treaties: of course, a fully-fledged 'federal (r)evolution' would certainly be possible in abstract, but the current political climate makes it rather unlikely. Thus, the paper considers possible federal developments within the current Treaty framework.

Among the several proposals formulated by institutional and academic actors, as a reaction in particular to the Hungarian and Polish constitutional crises, many seem to have been inspired, explicitly or implicitly, by mechanisms available to federal systems. There has been a certain emphasis on strengthening judicial procedures to ensure common values, broadening the mandate of the CJEU and/or of national courts as EU courts. Reliance on legal actors - mostly constitutional courts - is a feature which has been described as common to federations, and absent in IOs. Thus, some scholars have attempted to find ways to improve the enforcement of values, once again adopting a formulation closer to 
federations rather than IOs, where the emphasis tends to be on political and diplomatic sanctions (Jakab and Kochenov 2017).

The most explicitly federal proposal has been suggested by Andras Jakab, who argues that the EUCFR should become applicable to all domestic cases, irrespective of questions concerning the scope of EU law and any cross-border element (Jakab 2017). The CJEU, the argument goes, should judicially re-interpret Art. 51 of the Charter, making the rights contained therein applicable even in purely domestic cases. The Charter would thus become 'a real and fully fledged bill of rights in the European Union' (Jakab 2017: 194), constructing a system of semi-centralized judicial review, in which local courts could use the 'federal' bill of rights in purely domestic cases, and the Court of Justice would be called to support them by interpreting the Charter via preliminary references. The proposal takes as a starting point the idea that sanctioning or expelling a Member State does not truly contribute to resolving the problems on the ground. Such an approach fails to offer adequate protection to the human rights of citizens affected by the policies of the government in question. Jakab thus suggests a radical federal transformation of the entire European project - a 'fresh step towards federalization' (Jakab 2017: 197) - considering the centralizing effects that a universally applicable bill of rights may have (Lenaerts. 1996; Eeckhout 2002). ${ }^{\text {LXVI }}$ Indeed, 'there is hardly anything that has greater potential to foster integration than a common bill of rights, as the constitutional theory of the United States has proven' (Cappelletti 1989: 395). Therefore, making the federal bill of rights directly applicable to domestic cases would be a clear shift of the integration process towards the creation of a true European federation.

While the idea suggested by Jakab is certainly the most explicitly federal project and would produce the most far-reaching effects in terms of transformation of the European project, other proposals could also have a comparable impact on the integration structure. The much-discussed 'Reverse Solange' doctrine is certainly one of those (Von Bogdandy et. al 2012). ${ }^{\text {LXVII }}$ The proposal similarly relies on national courts, supported by the CJEU via preliminary rulings. However, it does not claim that the EUCFR should always be applicable in purely internal situations, but only when there are systemic problems threatening respect for the 'essence' of fundamental rights. Thus, in an ordinary situation, the limits of Art. 51 of the EUCFR would still apply, because there is a presumption that Member States comply with the common values of Art. 2 of the TEU: this is the 'Solange' 
part, a reference to the Solange doctrine of the German Constitutional Court on the fundamental rights' review of EU legislation. In this way, the EU and the CJEU would show a form of deference to national legal orders, according to the proponents of 'Reverse Solange'. This presumption is however rebuttable when systemic problems are not adequately addressed at the national level.

The doctrinal ground for the proposal is the concept of EU citizenship, in particular, as interpreted by the CJEU in Zambrano. ${ }^{\text {LXVIII }}$ In the latter the Court held that EU citizenship rights may be applicable in purely internal situations when the 'genuine enjoyment of the substance of the rights' is at stake. ${ }^{\text {LXIX }}$ According to the Reverse Solange doctrine, in cases of systemic deficiencies, the concept of respect for human rights - an EU founding value as per Art. 2 of the TEU - is de facto divested of any concrete meaning, thus prompting a call for an application of the EUCFR as an emergency measure. The federal impact of such a development would be felt in two distinct senses. First, there are the considerations seen above in relation to Jakab's proposal. Despite its more careful dogmatic construction, Reverse Solange still implies radical overhauling of the limits of Art. 51 of the Charter. Besides, due to the rather open-ended nature of the concepts of 'essence of fundamental rights' and 'systemic problems', it may in the medium-term produce a similar transformation of the Charter in a universally applicable bill of rights, following a series of expansive readings by the CJEU. Secondly, it would give a significant boost to the concept of EU citizenship, possibly fulfilling its 'destiny' as 'the fundamental status of nationals of the Member States, ${ }^{\mathrm{LXx}} \mathrm{A}$ transformation along these lines would be radical. In the most precarious situations, where their human rights are (systematically) violated, citizens of Member States would rely not on national law or on the national constitution, but on EU citizenship and EU fundamental rights. This would be possible even in the absence of any cross-border element. The impact of such as solution would be relevant both symbolically, with the EU offering protection where national authorities fail to do so, and from a more technical point of view, as it would obfuscate the existing limits to the scope of application of EU law.

Finally, a third proposal to be considered is Kim-Lane Scheppele's 'systemic infringement procedure' (Scheppele 2016). While the idea in itself is not explicitly federal, and in fact relies on a traditional EU law enforcement mechanism, it would arguably entail a significant transformation of the current state of affairs. The proposal argues that the 
Commission should bundle together, in a single infringement action, a series of breaches of EU values, directly on the basis of a breach of Art. 2 of the TEU. If the Member State in question does not adequately address the observation of the Commission in the precontentious stage, the Court of Justice would then declare that the state has breached EU values in a systemic manner. ${ }^{\text {LXXI }}$ The Member State would thus be called on to remedy the systemic breach of EU values, and financial sanctions could be imposed via Art. 260 TFEU's procedure if it failed to do so. Scheppele suggests that financial sanctions could also involve the suspension of structural funding to the Member State.

This procedure would therefore entrust the Court of Justice with further competences in monitoring Member States' compliance with EU common values. Whilst this would not transform the nature of the EUCFR as such, it is likely that due to the vagueness of the other values mentioned in Art. 2 of the TEU, the Charter would be used as a benchmark to assess whether a Member State has breached EU values, thus indirectly overcoming the limits of Art. 51 of EUCFR. The proposal would also weaken the traditional separation between matters falling within and outside the scope of EU law. As discussed earlier, the principle of primacy of EU law only applies within the scope of EU law, where there are substantive norms and legislation. In the current framework, the values of Art. 2 are largely outside the scope of EU law, and thus the concept of primacy is not applicable to the provision. However, if EU values are transformed in legally binding obligations and therefore in 'traditional' EU law they would also enjoy primacy over any national constitutional norm. This would bring to the EU system a clear element of hierarchy, typical of federal systems, where the federal constitution is superior to statutes and laws of the sub-entities. In addition, as is often the case in federal systems, it would be a court the CJEU - to supervise respect for constitutional values.

As may already be evident from the illustration of the proposals, the current constitutional framework presents several obstacles to the deployment of 'federal means' in order to protect the Union's common values. These obstacles are both legal and theoretical. Firstly, there is Art. 7 itself, which, as seen above, does not employ a federal paradigm and almost completely excludes the CJEU from the system. In relation especially to the proposal of systemic infringement actions, it can be argued that Art. 7 works as a lex specialis for the protection of Art. 2 values, thus excluding other traditional mechanisms of enforcement of EU law - including Art. 258 TFEU ${ }^{\mathrm{LXXII}}$ - when a situation falls outside the 
scope of EU law. Hence the different model of Art. 7 and the roles it assigns to EU institutions would be called into question if the Art. 258 procedure is used through the backdoor.

Then there is Art. 51 of the EUCFR. During the drafting of the Charter, the Member States, were acutely aware of the potential federal effect of such a document, and were careful in limiting the scope of its application. They therefore stressed that the Charter 'does not extend the field of application of Union law beyond the powers of the Union or establish any new power or task for the Union, or modify powers and tasks as defined in the Treaties'. Moreover, Art. 51 added that 'The provisions of this Charter are addressed ... to the Member States only when they are implementing Union law'. The language of Art. 51 suggested a scope of application more limited than the traditional case law of the CJEU, which had already declared that its jurisdiction extended to reviewing Member States' measures derogating from Union law. The situation was clarified by the CJEU in Akerberg Fransson, when it was held that 'where national legislation falls within the scope of European Union law, situations cannot exist which are covered in that way by European Union law without those fundamental rights being applicable'. ${ }^{\text {LXXII }}$ To put it simply, where EU law applies, the EUCFR applies. However, the clarification is limited, because it remains difficult and controversial to ascertain when EU law applies (Fontanelli 2013). Even in the absence of a clear answer to this question, there are no dobuts that Art. 51 still poses limits to the scope of application of the Charter. In other words, there will still be cases where the Charter does not apply, because the matter does not fall within the scope of EU law. ${ }^{\text {LXxiv }}$

It may be too simplistic to say that the proposals illustrated above do not take into sufficient account what the law is, but the limitation of Art. 51 of the EUCFR is so explicit that it can hardly be ignored, even more so when considering that the intention of the drafters of the provision was clearly to limit the applicability of the Charter. Jakab's rebuttal (Jakab 2017: 199) is not entirely convincing: while it is true that the CJEU in other leading cases has gone against the apparent wording of a Treaty provision, ${ }^{\mathrm{LxV}}$ in this context there is no ambiguity and there is the obvious desire of the drafters to prevent that effect. The Court of Justice would go explicitly contra legem, and its legitimacy would most likely be severely affected, were it to take that decision. On the other hand, the Heidelberg group attempts to square the provision of Art. 51 with their Reverse Solange doctrine, via Union 
citizenship and the concept of 'essence' of fundamental rights. In practice, however, the proposal would also envisage an application of the Charter to cases currently excluded by Art. 51, and it is questionable whether the Court has the authority and the legitimacy to take such a step.

Finally, there is a set of theoretical arguments relating to the current nature of the EU and of the integration process, supported by the provision of Art. 4(2) of the TEU, protecting the national and constitutional identity of Member States. As seen in Section 2, some authors have argued that the framework of constitutional homogeneity is not applicable to the EU framework, since there is a great diversity in terms of the institutional organisation of the Member States, and the EU does not have a general competence to harmonise national constitutional systems. Hence Art. 4(2) of the TEU is in place precisely to protect the existing diversity of constitutional choices, excluding a convergence towards a single model. Armin von Bogdandy himself suggested the use of the more nuanced concept of 'structural compatibility', which accordingly demands a lower threshold than 'homogeneity' (Von Bogdandy 2009). This understanding of the integration process and of the nature of the relationships between the EU and the Member States calls into question a complete federalization of EU oversight, which would be entrusted to a Court with farreaching competences to decide on any breach of fundamental rights in the Union or on the compatibility of constitutional arrangements with rather un-defined EU values. Expanding the jurisdiction of the CJEU would have the centralising and harmonising effects which Art. 4(2) of the TEU seems to exclude. It must be emphasized that these limits do not necessarily derive from a constitutionally pluralist view (Avbelj and Komarek 2012). More simply, this is what the current constitutional framework prescribes, imposing limits to EU's judicial oversight of fundamental rights and providing a political rather than a legal procedure for upholding common values. In this framework, values are not simply imposed from the centre to the peripheries, but constantly co-determined between the two levels. ${ }^{\text {LXXVI }}$ EU values are informed by national conceptions and at the same time they aim to shape the development of national values. This is in contrast to federal experience, where the monopoly of the interpretation of constitutional values rests with constitutional or supreme courts, and a common uniform conception is sought and then exported to the sub-entities. In the EU, however, it seems hardly desirable to transform this conception of 
the integration process through judicial procedures, in the absence of a conscious political choice.

In conclusion, the federal solutions proposed seem to be not only legally infeasible, but also undesirable at the moment. To be more precise, it is not desirable that these solutions are adopted without explicit political deliberations. The traditional 'integration through law' model as shaped by Court's decisions does not seem fit for this type of constitutional questions with a strong political component.

\section{Conclusions: Upholding values and the EU constitutional balance}

While a federal turn may be neither a feasible nor a desirable solution, EU institutions still have the responsibility to offer effective answers to on-going constitutional crises. The question has a crucial importance for the EU legal and political order, as recognised in section 2 of this work. But solutions cannot be imported from other contexts, either from federal systems or from the experience of other international and regional organisations. The EU and its own institutions should strive to find distinctive solutions, which acknowledge and respect the current constitutional balance between the Union and the Member States.

It is not the aim of this work to offer a detailed analysis of new solutions, but more modestly to identify some guidelines, which may contribute to finding a possible pattern for EU's intervention. In the first place, the EU should make full use of existing procedures and frameworks. This includes both the more political mechanism, including Art. 7 and especially its preventive arm, and legal ones. It is precisely a combination of the political and legal instruments available that may produce better results than those achieved so far. This combination has not been attempted until very recently; the Commission followed different approaches in Poland, where it deployed the Rule of Law Framework, and in Hungary, where it pursued more limited infringement actions on technical aspects of the reforms. A more comprehensive strategy, involving not only the Commission but also the Council and the Parliament, would arguably be beneficial in fostering cohesiveness and coherence. Nevertheless, there are some positive signs: all institutions are finally participating in the debate, including the Council. Furthermore, the Commission has for the first time combined the two approaches vis-à-vis Poland: it has finally activated Art. 7(1), 
adopted several Rule of Law Recommendation, but also launched an infringement action on the 'Law on Ordinary Courts'. The combination of approaches and the mutual cooperation between institutions is one of the strengths of the EU legal and political order and may produce more positive results in fighting constitutional crises too.

Furthermore, even within the current constitutional framework, there is arguably room for infringement actions which are less narrowly framed, where substantive concerns regarding compliance with EU values emerge more directly. ${ }^{\text {LXVVII }}$ This is possible especially in cases of systemic human rights problems. The Commission could rely more intensively on the Charter in infringement actions, as a support to an infringement of another provision of EU law or even as the main ground for the action in cases falling within the scope of EU law. Until today, the Commission has almost never done so (Lazowski 2013), but this is merely an institutional choice and not a limit imposed by Art. 51 of the Charter. There are some positive signs in this respect too. In the recent actions against Hungary and Poland, the Commission has referred to several provisions of the Charter as grounds for infringement. This allows the Commission to construct the action in less narrow terms, and consequently, if the CJEU were to find a breach of EU law obligations, the Member State would be forced to comply not only with the technical requirements, but would also have to ensure respect for EU fundamental rights.

Future reforms and changes to the system, if not undertaken within the context of a broader process of Treaty change, should also respect the limits of the current framework. Much could still be improved even without a fully federal 'twist'. In the first place, the EU could create a comprehensive monitoring scheme, as suggested by the European Parliament with its 'Values Scoreboard'. ${ }^{\text {LXxvIII }}$ The Commission Rule of Law could be strengthened, extending it to all Art. 2 values and possibly making the activation of Art. 7 automatic if the state in question fails to take action after a Rule of Law Recommendation. Structural funds' conditionality is an option to be considered and studied, although it raises complex constitutional and technical questions. But also, and perhaps more significantly, the EU could aim to identify clearer standards and develop common conceptions of the values of Art. 2. 'Mainstreaming' values into secondary law is one option to be pursued, but the EU may also aim to draft guidelines or a checklist similar to the one approved by the Venice Commission. ${ }^{\text {LXxIX }}$ It is important, however, that the process involves national actors, and it is not perceived as an imposition from the center to the periphery. 
Finally, it should be acknowledged that finding an effective solution to current challenges requires more than legal or doctrinal tricks, or a ruling of the CJEU. Upholding constitutionalism requires an intervention in the societal and cultural dimension too. ${ }^{\text {Lxxx }}$ The EU is not the only player in the field. It is therefore crucial that national actors perceive its intervention as legitimate and objective, otherwise it may become counterproductive. In order to avoid this, EU institutions should be careful not to overstep the boundaries of the current constitutional settlement, including the principle of national and constitutional identity.

\footnotetext{
* Matteo Bonelli, PhD Researcher, Faculty of Law, Maastricht University. The author would like to thank the participants to the MoreEU Conference at Nova School Lisbon on 22-23 May 2017, in particular Daniel Thym, Nuno Picarra, and Niels Tack, and the anonymous reviewer for their useful comments. The usual disclaimer applies. The paper was finalised on 30 October 2017. Following developments are only briefly mentioned in footnotes.

I See Art. 2 TEU: 'The Union is founded on the values of respect for human dignity, freedom, democracy, equality, the rule of law and respect for human rights, including the rights of persons belonging to minorities. These values are common to the Member States in a society in which pluralism, non-discrimination, tolerance, justice, solidarity and equality between women and men prevail'.

II Whilst President Duda's veto temporarily halted the adoption of two of the three reforms, the whole package was ultimately approved in December 2017.

III See European Parliament, Resolution of 17 May 2017 on the situation in Hungary, Doc. 2017/2656(RSP). For further analysis of the Art. 7(1) procedure, see Section 3.

IV European Commission - Press release - Hungary: Commission takes second step in infringement procedure on Higher Education Law, Brussels, 13 July 2017; and European Commission - Press release, Infringements - Hungary: Commission launches infringement procedure for law on foreign-funded NGOs, Brussels, 13 July 2017.

v European Commission - Press release, European Commission acts to preserve the rule of law in Poland, Brussels, 26 July 2017.

VI In December 2017, the Commission adopted a Fourth Rule of Law Recommendation and issued for the first time a reasoned opinion under Article 7(1) TEU, calling the Council to establish a 'clear risk of a serious breach' of EU values.

VII See Council of the European Union, Outcome of the Council Meeting, Brussels, 16 May 2017, Doc 9299/17: 'The Commission informed the Council on the state of play of its dialogue with Poland on the rule of law. Ministers emphasised the importance of continuing the dialogue between the Commission and Poland'.

VIII See most of the contributions in Closa and Kochenov 2016. Specifically on the Hungarian case, see Pech and Scheppele 2016..

IX The main academic proposals, including Jan-Werner Muller's 'Copenhagen Commission', the 'Reverse Solange' doctrine developed in Heidelberg, and the systemic infringement actions' idea of Kim Lane Scheppele, have been collected in Closa and Kochenov 2016, and Jakab and Kochenov 2017. On the institutional front, the European Parliament has drafted a EU Mechanism on Democracy, the Rule of Law and Fundamental Rights: see EP, Resolution of 25 October 2016, Doc. 015/2254(INL).

$\mathrm{x}$ More on the distinction in Sections 4 and 5.

XI See e.g. Gavison 2002: the 'basic values and commitments' of a community are one of the traditional features of almost any constitution worldwide.

XII See Inter-American Democratic Charter, Arts. 2-3.

XIII See CARICOM Charter of Civil Society.

XIV See African Charter on Democracy, Elections and Governance, Art. 2.

XV As for example in the Inter-American Democratic Charter for the Organization of American States (OAS) and the African Charter on Democracy, Elections and Governance for the African Union.
} 
XVI As in CoE and UN, for example.

XVII An example is Art. 2 of the Inter-American Democratic Charter.

XVIII See for example the Preamble of the Irish Constitution.

XIX See Art. 1 of the Italian Constitution.

$\mathrm{xx}$ Admittedly, it is still controversial whether Spain may be considered a fully federal system. The paper does not take aim to take a stance in the discussion and will only consider it 'federal' for the purpose of this work. On the debate: see Sala 2013.

xxI On the content of these principles, see Art. 20 of the Basic Law.

XXII See also Amendment XIV.

XXIII Art. 51 of the Swiss Constitution: 'Each Canton shall adopt a democratic constitution'.

xxIv European Council, Conclusions of the Presidency, Copenhagen, 21-22 June 1993, SN 180/1/93 REV 1.

xxv See CARICOM Charter of Civil Society.

xxvI See also previous Article 23 of the German Basic Law.

xxVII On the origins of the concept of Verfassungshomogenität, see Schmitt 2008.

XXVIII This is defined as the 'all-affected principle': Goodin 2007.

XXIx See Closa 2016, for the qualification of the provisions as democracy protecting clauses. On the other hand: Mangiameli 2013; Delledonne 2016.

xxx See for example on the rule of law: Loughlin 2010, Chapter 11: "Rechtsstaat, Rule of Law, l'Ètat de droit".

xxxi See for example Art. 31 of the German Basic Law.

xxxil See for example Art. 19 TFEU on non-discrimination.

xхxіII On the issue, see Scharpf 2007; the concept of demoicracy developed by Nicolaidis offers another illustration of the "democratic externalities" in the EU system: see for example Nicolaidis 2013.

xxxiv CJEU, Opinion 2/13 EU Accession to the ECHR, ECLI:EU:C:2014:2454, para 168.

xxxv CJEU, C-411/10 N. S. and others v Secretary of State for the Home Department and M. E. and Others ECLI:EU:C:2011:865.

xxxvi CJEU, Joined Cases C-404/15 and C-659/15 PPU, Pál Aranyosi and Robert Căldăraru v Generalstaatsanwaltschaft Bremen ECLI:EU:C:2016:198.

xxxviI ECtHR, M.S.S. v Belgium and Greece, Application No 30696/09, Judgment of 21 January 2011; ECtHR, Tarakhel v Switzerland, Application no. 29217/12, Judgment of 4 November 2014.

xxxvIII As noted by Closa, the 'institutional design of suspension mechanisms and provisions does not demonstrate significant divergence'; see Closa 2016: 387. There has been an 'institutional mimeses' as provisions has been frequently translated to different contexts.

XXXIX Examples of qualified majorities: Art. 20(d) CoE Statute: two-thirds vote of the Committee of Ministers, representing a majority of the CoE members; Art. 21 Inter-American Democratic Charter: two thirds of the Member States.

XL See Art. 8 of the CoE Statute.

XLI See Articles 4 and 30 of the Constitutive Act of the African Union, adopted in 2000 in Lomé. The same principle is affirmed in the African Charter on Democracy, Elections and Governance, in Articles 2 and 3 the procedure is then regulated in Chapter 8. Similarly, the Inter-American Democratic Charter provides (Art. 20) for the activation of sanctions "in the event of an unconstitutional alteration of the constitutional regime that seriously impairs the democratic order in a Member State"

XLII See Articles 5 and 6 of the United Nations Charter.

XLIII See Art. 21 of the Inter-American Democratic Charter, requiring a two-thirds vote of the Members of the OAS. After regional organizations in America follow a model similar the OAS: see MERCOSUR, Protocol of Ushuaia I and II; Andean Community, and the Union of South-American States.

XLIV See Art. 25 of the African Charter on Democracy, Elections and Governance.

XLV See Art. 84(3) and (4) of the German Basic Law.

XLVI See Art. 93(2) of the German Basic Law.

XLVII See Art. 93(4)(a) of the German Basic Law.

XLVIII See Art. 21(2) of the Basic Law. On the concept of militant democracy see Loewenstein 1937; more recently, Sajó 2004; Müller 2012.

XLIX Art. 87(a)(4) of the German Basic Law. 
L This paper has been conceived and concluded before the Catalan independence referendum and for reasons of time cannot deal with such events in a detail manner. This is the only reference to the Catalan crisis offered in this work.

LI Art. 161(2) of the Spanish Constitution.

LII See Articles 6 and 55 of the Spanish Constitution.

LIII US Supreme Court, Luther v Borden 48 U.S. 1(1849).

LIV US Supreme Court, Baker v Carr 369 U.S. 186 (1962).

LV 10 US Code 12406 National Guard in Federal Service.

LVI In 1957, during the Little Rock school crisis, the State governor resisted desegregation and ordered to close schools, deploying the national guard of the state to prevent the enforcement of the Supreme Court decision in Brown v Board of Educators, 347 U.S. 483 (1954). The President sent first a federal injunction against the use of the national guard and then deployed federal troops to enforce the federal courts' orders. For a more detail account: Freyer 1984.

LVII See Art. 169 of the Belgian Constitution.

LVIII Sanctions can then be removed via Art. 7(4).

LIX See Art. 269 TFEU.

LX The EP votes at qualified majority too: two-thirds of the votes cast, according to Art. 354 TFEU.

LXI Art. 7(3), italics added.

LXII Ivi.

LXIII As confirmed by the Commission in European Commission, 'A new EU Framework to strengthen the Rule of Law', Brussels, 19 March 2014, COM(2014) 158final/2.

LXIV See European Commission, Communication on Art. 7 of the Treaty on European Union. Respect for and promotion of the values on which the Union is based, Brussels, 15 October 2003, COM(2003) 606 final.

LXV Other options are Resolutions of the European Parliament and the Council Rule of law Dialogue, as well as the general activity of the Fundamental Rights Agency.

LXVI See also Opinion of Advocate General Sharpston in C-34/09 Zambrano ECLI:EU:C:2010:560.

LXVII von Bogdandy et al. 2012.

LXVIII CJEU, C-34/09 Zambrano ECLI:EU:C:2011:124.

LXIX Ivi, para. 42.

LXx CJEU, C-184/99 Grzelçy/k ECLI:EU:C:2001:458.

LXXI Escaping thus the problem of creative and symbolic compliance emerged during the infringement actions against Hungary: see Batory 2016.

LXXII With the latter being of course the lex generalis for the enforcement of 'ordinary' EU law.

LXXIII CJEU, C-617/10 Akerberg Fransson ECLI:EU:C:2013:105, para 21.

LXXIV The 'humanitarian visa' decision offers a concrete example: see CJEU, C-638/16 PPU, $X$ and $X$ ECLI:EU:C:2017:173.

LXXV Such as in its decisions on direct effect of directives: see e.g. CJEU, C-41/71 Van Duyn ECLI:EU:C:1974:133.

LXXVI For example, common constitutional principles, now explicitly recognised in Art. 6 TEU as one of the 'sources' of fundamental rights in the EU, have inspired the case-law of the CJEU and led the development of fundamental rights' protection in the Union.

LXXVII As opposed to more 'indirect' forms of protection: see Dawson and Muir 2013.

LXXVIII European Parliament, Resolution with recommendations to the Commission on the establishment of an EU mechanism on democracy, the rule of law and fundamental rights (Strasbourg, 25 October 2016) Doc. 2015/2254(INL).

Lxxix Venice Commission, 'Rule of Law Checklist' (Strasbourg, 18 March 2016), Doc. CDL-AD(2016)007.

LXxx With specific reference to Central and Eastern European states, see Blokker 2014.

\section{References}

- $\quad$ Alter Karen, 2003, Establishing the Supremacy of European Law: The Making of an International Rule of Law in Europe, Oxford University Press, Oxford. 
- Avbelj Matej and Komárek Jan (eds), 2012, Constitutional Pluralism in the European Union and Beyond, Hart Publishing, Oxford.

- $\quad$ Batory Agnes, 2016, 'Defying the Commission: Creative Compliance and Respect for the Rule of Law in the EU', Public Administration, XCIV(3): 685-699.

- $\quad$ Blokker Paul, 2014, New Democracies in Crisis?, Routledge, London.

- $\quad$ von Bogdandy Armin, 2012, 'Neither an International Organization Nor A Nation State: The EU as a Supranational Federation', in Jones Erik, Menon Anand and Weatherill Stephen (eds), The Oxford Handbook of the European Union, Oxford University Press, Oxford.

- von Bogdandy Armin and Bast Jürgen (eds), 2009, Principles of European Constitutional Law, Hart Publishing, Oxford.

- von Bogdandy Armin, Kottmann Matthias, Antpöhler Carlino, Dickschen Johanna, Hentrei Simon and Smrkolj Maja 2012, 'Reverse Solange - Protecting the Essence of Fundamental Rights against EU Member States', Common Market Law Review, XLIX(2): 489-520.

- de Búrca Gráinne, 2001, 'The Road Not Taken: The EU as a Global Human Rights Actor', American Journal of International Law, CV(4): 649-693.

- $\quad$ Cappelletti Mauro, 1989, The Judicial Process in Comparative Perspective, Oxford University Press, Oxford.

- $\quad$ Carothers Thomas, 1998, 'The Rule of Law Revival', Foreign Affairs, LXXVII(2): 95-106.

- Closa Carlos, 2016, 'Reinforcing EU monitoring of the rule of law: normative arguments, institutional proposals and the procedural limitations', in Closa Carlos and Kochenov Dimitry (eds), 2016, Reinforcing Rule of Law Oversight in the European Union, Cambridge University Press, Cambridge.

- Closa Carlos and Kochenov Dimitry (eds), 2016, Reinforcing Rule of Law Oversight in the European Union, Cambridge University Press, Cambridge.

- Closa Carlos, Palestini Céspedes Stefano and Castillo Ortiz Pablo, 2016, 'Regional Organisations and Mechanisms for Democracy Protection in Latin America, the Caribbean, and the European Union', EU-LAC Foundation.

- Cremona Marise, 2011, 'Values in EU Foreign Policy', in Evans Maurice and Koutrakos Panos (eds), 2011, Beyond the Established Legal Orders. Policy Interconnections between the EU and the Rest of the World, Oxford, Hart Publishing.

- Dawson Mark and Muir Elise, 2013, 'Hungary and the Indirect Protection of EU Fundamental Rights and the Rule of Law', German Law Journal, XIV(10): 1959-1980.

- Delledonne Giacomo, 2016, 'Homogénéité Constitutionnelle et Protection des Droits Fondamentaux et de l'Etat de Droit dans l'Ordre Juridique Européen', Politique européenne, no. 51: 86-109.

- Duxbury Alison B., 2011, The Participation of States in International Organisations - The Role of Human Rights and Democracy, Cambridge University Press, Cambridge.

- $\quad$ Eeckhout Piet, 2002, 'The EU Charter of Fundamental Rights and the Federal Question', Common Market Law Review, XXXIX(5): 945-994.

- Fontanelli Filippo, 'Hic Sunt Nationes: The Elusive Limits of the EU Charter and the German Constitutional Watchdog', European Constitutional Law Review, IX(2): 315-334.

- Franck Thomas, 1992, 'The Emerging Right to Democratic Governance', American Journal of International Law, LXXXVI(1): 46-91.

- Freyer Tony, 1984, The Little Rock Crisis: a Constitutional Interpretation, Greenwood, Westport, Connecticut.

- Gavison Ruth, 2002, 'What Belongs in a Constitution?’, Constitutional Political Economy, XIII(1): 89-105.

- Goodin Robert E., 2007, 'Enfranchising All Affected Interests and its Alternatives', Philosophy and Public Affairs, XXXV(1): 40-68.

- Hanschel Dirk, 2017, 'Enforcement of Federal Law against the German Lander', in Jakab Andras and Kochenov Dimitry (eds), 2017, The Enforcement of EU Law and Values - Ensuring Member States' Compliance, Oxford University Press, Oxford.

- Jakab Andras, 2016, 'The EU Charter of Fundamental Rights as the most promising way of enforcing the rule of law against EU Member States', in Closa Carlos and Kochenov Dimitry (eds), 2016, Reinforcing Rule of Law Oversight in the European Union, Cambridge University Press, Cambridge. 
- Jakab Andras and Kochenov Dimitry (eds), 2017, The Enforcement of EU Law and Values - Ensuring Member States' Compliance, Oxford University Press, Oxford.

- Kochenov Dimitry and Pech Laurent, 2015, 'Monitoring and Enforcement of the Rule of Law in the EU: Rhetoric and Reality', European Constitutional Law Review, XI(3): 512-540.

- $\quad$ Landau David, 2013, ‘Abusive Constitutionalism’, UC Davis Law Review, XLVII: 189-260

- Larik Joris, 2016 Foreign Policy Objectives in European Constitutional Law, Oxford University Press, Oxford.

- Lazowski Adam, 2013, 'Decoding a Legal Enigma: the Charter of Fundamental Rights of the European Union and infringement proceedings', ERA Forum, XIV: 573-587.

- Lenaerts Koen, 1996, 'Federalism and Rights in the European Community', in Ellis Katz and George Allan Tarr (eds), Federalism and Rights, Rowman \& Littlefield Publishers, Lanham.

- Loewenstein Karl, 1937, 'Militant Democracy and Fundamental Rights I', The American Political Science Review, $\operatorname{XXXI}(3):$ 417-432.

- López-Basaguren, Alberto, 2017, 'Regional Defiance and Enforcement of Federal Law in Spain', in Jakab Andras and Kochenov Dimitry (eds), 2017, The Enforcement of EU Law and Values - Ensuring Member States' Compliance, Oxford University Press, Oxford.

- $\quad$ Loughlin Martin, 2010, Foundations of Public Law, Oxford University Press, Oxford.

- Mangiameli Stelio, 2013, 'Article 2: The Homogeneity Clause', in Blanke Hermann-Josef and Mangiameli Stelio (eds), The Treaty on European Union (TEU) - A Commentary, Springer, Heidelberg.

- Müller Jan-Werner, 2012, 'Militant Democracy', in Rosenfeld Michael and Sajó András (eds), The Oxford Handbook of Comparative Constitutional Law, Oxford University Press, Oxford.

- Muller Jan-Werner, 2016, 'Should the EU Protect Democracy and the Rule of Law inside Member States?', European Law Journal, XXI(2): 143-160.

- Nicolaidis Kalypso, 2013, 'European Demoicracy and its Crisis', Journal of Common Market Studies, LI(2): 351-369.

- Oliver Peter and Stefanelli Justin, 2016, 'Strengthening the Rule of Law in the EU: The Council's Inaction', Journal of Common Market Studies, LIV(2): 1075-1084.

- $\quad$ Pech Laurent and Scheppele Kim Lane, 2016, 'The EU and Poland: Giving up on the Rule of Law',

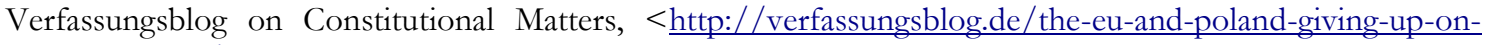
the-rule-of-law/ (last accessed 30-10-2017)

- $\quad$ Sadurski Wojciech, 2010, 'Adding Bite to a Bark: the Story of Article 7, E.U. Enlargement, and Jorg Haider', Columbia Journal of European Law, XVI(3): 385-426.

- $\quad$ Sajó András (ed), 2004, Militant Democracy, Eleven International, Utrecht.

- $\quad$ Sala Gemma, 2013, 'Federalism without Adjectives in Spain', Publius, XLIV(1): 109-134.

- $\quad$ Scharpf Fritz, 2007, Reflections on Multilevel Legitimacy, Max Planck Institute for the Study of Society, Cologne.

- $\quad$ Scheppele Kim-Lane, 2016, 'Enforcing the basic principles of EU law through systemic infringement actions', in Closa Carlos and Kochenov Dimitry (eds), Reinforcing Rule of Law Oversight in the European Union, Cambridge University Press, Cambridge.

- $\quad$ Schmitt Carl, 2008, Constitutional Theory, Duke University Press, Durham.

- Schroeder Werner (ed), 2016, Strengthening the Rule of Law in Europe - Form a Common Conception to Mechanisms of Implementation, Hart Publishing, Oxford.

- $\quad$ Sullivan Kathleen and Feldman Noah, 2013, Constitutional Law, Foundation Press, New York.

- Tushnet Mark, 2017, 'Enforcment of National Law against Subnational Units in the US', in Jakab Andras and Kochenov Dimitry (eds), The Enforcement of EU Law and Values - Ensuring Member States' Compliance, Oxford University Press, Oxford.

Court of Justice of the European Union

- $\quad$ CJEU, Case C-41/71 Van Duyn, ECLI:EU:C:1974:133.

- $\quad$ CJEU, Case C-184/99 Grzelcayk, ECLI:EU:C:2001:458.

- $\quad$ CJEU, Case C-34/09 Zambrano, ECLI:EU:C:2011:124.

- CJEU, Case C-411/10, N. S. and others v Secretary of State for the Home Department and M. E. and Others, ECLI:EU:C:2011:865. 
- $\quad$ CJEU, Case C-617/10 Akerberg Fransson, ECLI:EU:C:2013:105.

- CJEU, Opinion 2/13, EU Accession to the ECHR, ECLI:EU:C:2014:2454.

- CJEU, Joined Cases C-404/15 and C-659/15 PPU, Pál Aranyosi and Robert Căldăraru v Generalstaatsanwaltschaft Bremen, ECLI:EU:C:2016:198.

- $\quad$ CJEU, Case C-638/16 PPU, $X$ and X, ECLI:EU:C:2017:173.

European Court of Human Rights

- $\quad$ ECtHR, M.S.S. v Belgium and Greece, Application No 30696/09, Judgment of 21 January 2011.

- ECtHR, Tarakhel v Switzerland, Application no. 29217/12, Judgment of 4 November 2014.

United States Supreme Court

- $\quad$ US Supreme Court, Luther v Borden 48 U.S. 1(1849).

- $\quad$ US Supreme Court, Brown v Board of Educators, 347 U.S. 483 (1954).

- $\quad$ US Supreme Court, Baker v Carr 369 U.S. 186 (1962). 